\title{
EOSINOPHILIC ESOPHAGITIS Brief communication and review of the literature
}

\author{
Tonny Tanus \\ David Geffen School of Medicine UCLA \\ Kern Allergy Medical Clinic Inc. CA \\ Email: Drttanus@ucla.edu
}

\begin{abstract}
Abstrak: Esofagitis eosinofilik (EoE) merupakan inflamasi alergik pada esofagus yang secara klinis ditandai oleh gejala refluks, gangguan pencernaan, disfagia, nyeri perut kronis dengan kekambuhan sporadik, mual dan muntah. Sebagai penyebabnya ialah kondisi alergik terhadap alergen yang berasal dari makanan, lingkungan, atau keduanya. Dinding esofagus dipadati sangat banyak eosinofil. Kami melaporkan dua kasus EoE yaitu seorang laki-laki berusia 30 tahun dan seorang anak laki-laki berusia 11 tahun. Pemeriksaan yang dilakukan ialah esofagogastroduodenoskopi, biopsi, dan uji alergi. Diagnosis EoE ditegakkan oleh adanya eosinofil pada biopsi, dengan baku emas 15 eosinofil per lapangan pandang besar (LPB). Penelitian akhir-akhir ini mengajukan 5-7 eosinofil per LPB. Patologi EoE diduga diinduksi oleh makanan, kacang-kacangan, telur, dan kacang kedelai. Pengobatan yang diberikan ialah steroid topikal seperti fluticasone atau budesonide, dan proton pump inhibitors. Studi lanjut dibutuhkan untuk mengeksplorasi pengaruh pengobatan alergi lainnya, seperti cromolyn, allergen specific immunotherapy/desensitization, dan biological targeting eosinophils, antara lain anti IL-5. Menghindari alergen dan intervensi diet harus dilakukan serentak. Simpulan: Berdasarkan pemeriksaan yang dilakukan, diagnosis pasien-pasien ini ialah esofagitis eosinopfilik. Tantangan yang dihadapi ialah menentukan atau membuktikan alergen kausatif. Pengobatan ditujukan pada menghindari alergen, serta pemberian steroid inhalasi topikal dan proton pump inhibitors.
\end{abstract}

Kata kunci: esofagitis eosinofilik, perkembangan alergi, pengobatan alergi, eosinofil, alergi makanan.

\begin{abstract}
Eosinophilic esophagitis (EoE), clinically manifested with reflux symptoms, indigestion, dysphagia, chronic abdominal pain with sporadic flare ups, nausea and vomiting, is an inflammation of the esophagus, where the wall of the esophagus is congested with an abundance of eosinophils. The etiology of this EoE is the allergic condition to allergens derived from food, environment, or both. We reported two cases of EoE, a 30-year-old man and an 11-year-old boy. Their work up was comprised of esophagogastroduodenoscopy, biopsies, and allergy testing. The key to diagnosing EoE is the evidence of eosinophils in a performed biopsy, the gold standard being 15 eosinophils per high power field (eos/hpf). Recent studies suggest decreasing the standard to 5-7 eos/hpf. The pathology of EoE is thought to be induced by food and environmental allergens; the most causative food allergens in EoE would be cow's milk, nuts, eggs, and soy. The treatments typically employ topical steroids, such as Flovent (fluticasone) or Pulmicort (budesonide), and proton-pump inhibitors. More research is needed to explore the efficacy of other allergy treatments, such as cromolyn, allergen specific immunotherapy/desensitization, and biological targeting eosinophils, such as anti IL-5. Allergens avoidance and dietary intervention should be concomitantly used. Conclusion: Based on all the tests performed, the diagnosis of the patients was eosinophilic esophagitis. The challenge is to be able to determine or prove the causative allergens. Treatment usually includes avoidance of allergens, topical inhaled steroids, and proton-pump inhibitors.
\end{abstract}

Keywords: eosinophilic esophagitis, allergy work up, allergy treatment, eosinophils, food allergy. 


\section{CLINICAL PRESENTATIONS}

Patient 1 is a 30 -year-old man with a history of dysphagia and heart burn for several years. An esophagogastroduodenoscopy with biopsy showed evidence of an early scar and stricture at $42 \mathrm{~cm}$ in the distal esophagus, which was opened significantly by the passage of the endoscope. Multiple biopsies were taken of this distal part of the esophagus, showing more than 25 eosinophils in one high power field (eos/hpf). He was diagnosed with EoE. An allergy test is planned and a dietary regimen is to be instituted according to the allergy test results. The patient was prescribed the topical steroid, Flovent HFA 110 with 2 puffs to be taken in twice daily.

Patient 2 is an 11 year old boy with a two-year history of fruit and nut allergies, causing nasal congestion, runny nose, and difficulty in breathing and abdominal pain, and experiencing heart burn. A skin prick test was administered to the patient, showing positive allergy results to beans, cabbage, dairy products, fruits, nuts, potatoes, as well as pollens and cats. An esophagogastroduodenoscopy was performed. The esophagus was found to have diffuse linear striations as well as circular rings. The endoscopic biopsy indicated eosinophil-rich esophagitis, with greater than 50 eos/hpf. The patient, received Flovent HFA 110 with 2 puffs to be taken in twice daily, and levocetirizine dihydrochloride $5 \mathrm{mg}$ once daily. Consulting a dietician was recommended to keep these foods out of his diet, whilst maintaining a nutritional balance.

\section{DISCUSSION}

Eosinophilic esophagitis (EoE) is clinically characterized with a multitude of symptoms, often mimicking reflux symptoms, indigestion, dysphagia, chronic abdominal pain with intermittent flare ups, nausea, and vomiting. In children, we can see a disinterest in eating and a failure to thrive associated with the above symptoms. Chronic food related behavioral issues are often seen. ${ }^{1}$

The gold standard for diagnosing this condition is the presence of eosinophils in the biopsy of the esophagus. The initial requirement was for 15 eos/hpf. ${ }^{1}$ However, other studies showed that a significant percentage of patients was more likely to have EoE with just more than 7 eos/hpf. ${ }^{2}$ These patients with $>7$ eos/hpf were more likely to fail conventional anti-reflux therapy and be responsive to EoE therapy. DeBrosse et $\mathrm{all}^{3}$ proposed that the diagnostic criterion of 15 eos/hpf should be decreased to 5 eos/hpf because of their long-term pediatric study which showed that patients with counts as low as 5 eos/hpf are associated with an increased risk of dysphagia in adulthood. They followed 198 cases of pediatric EoE over the span of fifteen years, reviewed health related questionnaires, esophageal biopsy specimens, and matched them with controls including chronic esophagitis patients. Patients with higher eosinophilic counts having undergone childhood endoscopy were more likely to have dysphagia at an odd ratio of 1.6 every $10 \mathrm{eos} / \mathrm{hpf}$. Of note, other factors also associated with a higher incidence of adult dysphagia in these patients include food allergies (odds ratio 2.7), asthma (odds ratio 2.1) and the worse one was allergic rhinitis (odds ratio 3.5). Hence work ups for allergic rhinitis and food allergies are becoming standard practice.

The endoscopic features of EoE are characteristic but not specific. Diffuse white plaques and linear furrowing are typical. Other findings include erythema, edema, granularity or nodularity, concentric rings and strictures. ${ }^{4}$ Upper GI endoscopy score has been developed looking at those features: pallor, white plaques, linear furrows, and concentric rings or stricture. Appearance was recorded at three levels, proximal $(3 \mathrm{~cm}$ below the cricopharyngeal muscle), midpoint (between the gastroesophageal junction and the cricopharyngeal muscle), and distal $(3 \mathrm{~cm}$ above the gastroesophageal junction). The upper GI endoscopy scores are: zero points 
for absent feature; 1 if the feature was present at any 1 or 2 levels; and 2 if the feature was present at all three levels. Therefore, the maximum number of points was $8 .^{5}$ The above study also concluded that findings of dysphagia and anorexia or early satiety correlate most with higher esophageal inflammatory scores, and EoE patients can often be distinguished from GERD patients based on the above symptoms.

Because having an atopic condition carries a worse prognosis for EoE, many studies have attempted to link which specific allergens are associated with EoE. The skin prick testing or in-vitro testing for environmental allergens are encouraged to hopefully identify avoidable allergens which may reduce symptoms and medication reliance. Up to $93 \%$ of $\mathrm{EoE}$ patients in one study had at least one positive skin test to one or more inhalants. ${ }^{6}$ Positive skin testing is defined as a wheal and flare reaction that has a wheal at least 3 $\mathrm{mm}$ (in greatest diameter) larger than the negative control. At least one third of $\mathrm{EoE}$ patients in one series had multiple mold and pollen sensitivities that were often associated with grain and legume sensitivity. The researcher also noted that inhalant-sensitivity was found as frequently as food sensitivity. ${ }^{1}$

EoE can also be exclusively caused by aero-allergen as described by Fogg et al. ${ }^{7}$ Patients with seasonal exacerbations of their EoE have been described due to their aero-allergies. A normal panel of prick testing for adults usually contains 75-80 environmental allergens. In pediatric EoE patients, a panel of 38 common inhalant allergens has been studied. Interestingly, using this panel, most of the positives were outdoor allergens. In asthma studies, dust mites and dandilion allergies were prevalent, while in EoE, pollens and molds seem to be more significant. ${ }^{1}$ The obvious frustrating part of environmental allergies, is that they may be able to be treated using medications, immunotherapy, antibodies or some other yet to be proven anti-cytokines, but these allergies are practically unavoidable.

Expansive research has been dedicated to find the causative food allergies in EoE which may have more value if these problematic foods can be avoided without causing harm. Correlating skin prick tests to foods, food patch tests, and in vitro results with histology and symptoms scores of EoE have been done multiple times. A standard 16-food panel has been used and recommended which includes: eggs, milk, wheat, soy, peanuts, cashews, shrimp, beef, chicken, pork, rye, oats, corn, peas, tomatoes, and potatoes. ' If causative allergens are defined and avoided, they can lead to a resolution of symptoms, and if reintroduced can lead to a return of symptoms. The most common causative foods are milk, eggs, wheat, rye, and beef. ${ }^{8}$ Another more recent series has shown that cow's milk, nuts, eggs, and soy are the most common food allergens in EoE. ${ }^{6}$ An aggressive dietary treatment approach which was done in Spain empirically removing 6 foods from the diet showed significant improvement and were able to induce remission for up to 3 years in the adult patients with EoE. The foods were cereals, milk, eggs, seafood, legumes including peanuts and soy. ${ }^{9}$ More than $30 \%$ of the patients in that series had 3 or more food triggers. Cow's milk was the most common food antigen $(61.9 \%)$, followed by wheat (28.6\%), eggs (26.2\%), and legumes $(23.8 \%)$. Similar findings have been found in other studies including a study in the USA which showed wheat, milk, soy, and, nuts as the most frequently implicated foods. ${ }^{10}$

There is really no long term data on children with food allergies. Earlier studies in Europe showed most children (upwards of $80 \%$ ) outgrew their milk allergies by the age of $4 .{ }^{11}$ Later studies showed only approximately $20 \%$ of children developed tolerance by age 4 but most outgrew it by age $16 .{ }^{12}$ A more recent large USA study involving data from over 40,000 children found $50 \%$ of children with a history of milk allergies reported being tolerant to milk by age $4 .{ }^{13}$ It would be interesting if 
we can follow these children and determine the incidence of EoE later in life even in those children who "supposedly" have outgrown their food allergies. These studies have also shown that as in EoE, food allergy patients with concomitant allergic conditions such as asthma and atopic dermatitis, tend to have more severe diseases and are not as likely to outgrow their conditions. Yet to be determined is whether or not these are the patients who will eventually develop EoE. ${ }^{14}$

Treatment of EoE has to first include dietary and nutritional intervention. Many have nutritional risk factors including abdominal discomfort, poor appetite, and especially in children, vomiting, food refusal, and poor feeding behaviors. ${ }^{14} \mathrm{EoE}$ patients often have to undergo a trial of elimination diet including avoidance of proteins such as milk, soy, eggs, nuts, and fish. In children where the dietary choices are limited, this can present a serious problem. Protein intake as per expert recommendation should comprise at least $10 \%$ of the dietary intake. ${ }^{14}$ Therefore, careful consideration for over prescribing dietary restrictions has to be given to prevent new problems including malnourishment.

In the USA and Europe, availability of non-allergenic dairy and soy-free amino acid supplemental drink (such as Neocate) may make it somewhat easier to manage these EoE patients but limitations including few choices of flavor and added cost of these expensive drinks could derail the treatment plans. For those persistently symptomatic patients, or those whose allergens are not able to be identified or to be avoided due to practical reasons, then optimal medications have to be emphasized.

The first line agent is topical steroids such as fluticasone (Flovent) or budesonide (Pulmicort) usually by inhaling and swallowing. Our clinic usually started mimic dosages of 440 ug daily for moderately persistent asthmatics, although in the literature, dosages have been titrated upward depending on several criteria. ${ }^{15}$
Other agents including Gastrocrom (cromolyn) can be taken prior to meals. Though the efficacy of cromolyn in its many topical forms including nasal sprays, MDI, and nebulizers has been debated over the years. It is a very safe medication and the availability of generic oral formulation makes it accessible. The usual dose is 100$200 \mathrm{mg}$ in liquid ampules. Proton pump inhibitor (PPI) such as omeprazole or lansoprazole has to be implemented on an ongoing basis as well.

\section{CONCLUSION}

Eosinophilic esophagitis is an allergic inflammatory condition of the esophagus. It is caused by the patient's allergies either to foods or environmental allergens, or both. The challenge is to be able to determine or prove the causative allergens. Treatment usually includes avoidance and topical inhaled steroids. Other potential treatments are comprised of cromolyn, immunotherapy, and another future therapeutic option may contain anti-eosinophilic cytokine such as anti IL-5.

\section{REFERENCES}

1. Erwin EA, James HR, Gutekinst HM, Russo JM, et al. Serum IgE measurement and detection of food allergy in pediatric patients with eosinophilic esophagitis. Annals of Allergy, Asthma \& Immunology. 2010;104:496-502.

2. Ruchelli E, Wenner W, Voytek T, Brown K, Liacouras C. Severity of eosophageal eosinophilia predicts response to conventional gastroesophageal reflux therapy. Pediatr Dev Pathol. 1999;2:15-18.

3. DeBrosse CW, Franciosi JP, King EC, et al. Long-term outcomes in pediatriconset esophageal eosinophilia. J Allergy Clin Immunol. 2011;128:132-8.

4. Furuta GT, Liacouras CA, Collins MH, et al. Eosinophilic esophagitis in children and adults: a systematic review and consensus recommendations for diagnosis and treatment. 
Gastroenterology. 2007;133:1342-63.

5. Aceves SS, Newbury RO, Dohil MA, Bastian JF, Dohil R. A symptom scoring tool for identifying pediatric patients with eosinophilic esophagitis and correlating symptoms with inflammation. Ann Allergy Asthma Immunol. 2009;103:401-6.

6. Penfield JD, Lang D, Goldblum JR, Falk GW. The role of allergy evaluation in adults with eosinophilic esophagitis. J Clin Gastroenterology. 2010;44:22-27. Lang DM. Eosinophilic Esophagitis: Utility of Allergy / Immunology evaluation. Respiratory Exchange 2009, Fall issue, 12.

7. Fogg MI, Ruchelli E, Spergel JM. Pollen and eosinophilic esophagitis. J Allergy Clin Immunol. 2003;112:796-7.

8. Spergel JM, Beausoleil JL, Mascarenhas M, Liacouras CA. The use of skin prick tests and patch tests to identify causative foods in eosinophilic esophagitis. J Allergy Clin Immunol. 2002;109:363-8.

9. Lucendo AJ, Arias A, Gonzalez-Cervera J, Yague-Compadre JL, et al. Empiric 6-food elimination diet induced and maintained prolonged remission in patients with adult eosinophilic esophagitis: A prospective study on the food cause of the disease. Gut. 2011;60(suppl 3):A42.
10. Gonsalves N, Yang GY, Doerfler B, Ritz $\mathbf{S}$, et al. Elimination Diet effectively treats eosinophilic esophagitis in adults; food reintroduction identifies causative factors. 2012;152:1451-9.el.

Gastroenterology.

11. Host A, Halken S. A prospective study of cow milk allergy in Danish infants during the first 3 years of life: clinical course in relation to clinical and immunological type of hypersensitivity reaction. Allergy. 1990;45:587-96.

12. Skirpak JM, Matsui EC, Mudd K, Wood RA. The natural history of IgE mediated cow's milk allergy. J Allergy Clin Immunology. 2007;120:1172-7.

13. Warren CM, Jhaveri S, Warrier MR, Smith B, Gupta RS. The epidemiology of milk allergy in US children. Ann Allergy Asthma Immunol. 2013;110:370-4.

14. Groetch M, Nowak-Wegrzyn A. Practical approach to nutrition and dietary intervention in pediatric food allergy. Pediatric Allergy and Immunol. 2013;24:212-21.

15. National Heart, Lung, and Blood Institute. Expert Panel Report 3: Guidelines for the Diagnosis and Management of Asthma 2007. J Allergy Clin Immunol. 2007;120:S94-138. 